NBER WORKING PAPER SERIES

\title{
MACROPRUDENTIAL POLICY IN A WORLD OF HIGH CAPITAL MOBILITY: POLICY IMPLICATIONS FROM AN ACADEMIC PERSPECTIVE
}

\author{
Charles Engel \\ Working Paper 20951 \\ http://www.nber.org/papers/w20951
NATIONAL BUREAU OF ECONOMIC RESEARCH
1050 Massachusetts Avenue
Cambridge, MA 02138
February 2015

This first draft of this paper was originally prepared as background notes for 47th SEACEN Governors' Conference, Seoul, Korea, 13-14 February, 2012. I thank Javier Bianchi, Menzie Chinn, Kristin Forbes, Jeffrey Frankel, Olivier Jeanne, Anton Korinek, Jonathan Ostry, and Andy Rose for useful comments on various versions of this paper. The views expressed herein are those of the author and do not necessarily reflect the views of the National Bureau of Economic Research.

NBER working papers are circulated for discussion and comment purposes. They have not been peerreviewed or been subject to the review by the NBER Board of Directors that accompanies official NBER publications.

(C) 2015 by Charles Engel. All rights reserved. Short sections of text, not to exceed two paragraphs, may be quoted without explicit permission provided that full credit, including $\odot$ notice, is given to the source. 
Macroprudential Policy in a World of High Capital Mobility: Policy Implications from an Academic Perspective

Charles Engel

NBER Working Paper No. 20951

February 2015

JEL No. F33,F36,F42

\begin{abstract}
The paper explicates the issues raised for macroprudential regulation in a global economy with high capital mobility. The study surveys the recent literature and aims to translate the academic rationale for such policies, in which market imperfections lead to external effects that require policy interventions. The new economics of capital controls is addressed, in which capital controls may be introduced to reduce financial market distortions or to help stabilize exchange rate movements in the face of other market distortions. The empirical literature on the effectiveness of such policies is surveyed.
\end{abstract}

\author{
Charles Engel \\ Department of Economics \\ University of Wisconsin \\ 1180 Observatory Drive \\ Madison, WI 53706-1393 \\ and NBER \\ cengel@ssc.wisc.edu
}


This study is intended to provide a framework from an academic perspective for discussion of how high international capital mobility influences the choice and implementation of macroprudential policies. There are two main themes. First, there may be reasons for countries to impose prudential controls on capital inflows in order to put some constraints on "overborrowing”. Second, when capital is mobile, countries that impose macroprudential regulations on domestic financial institutions are subject to pressures arising from the global nature of international capital markets. International cooperation and reciprocity is necessary.

Hanson, et al. (2011) contrast “microprudential” and “macroprudential” approaches to regulating financial markets:

A microprudential approach is one in which regulation is partial-equilibrium in its conception, and is aimed at preventing the costly failure of individual institutions. By contrast, a macroprudential approach recognizes the importance of generalequilibrium effects, and seeks to safeguard the financial system as a whole. (p. 3)

The term "macroprudential regulation" tends to be associated with the policy of countercyclical capital requirements for financial institutions, but in fact there are many other policy instruments that have been considered. In fact, there has been an enormous literature in the past few years that has addressed this subject. Indeed, the discussion about macroprudential regulation precedes the global financial crisis by many years, and was an active area of discussion and research at the Bank for International Settlements and the International Monetary Fund in the decade before the crisis. ${ }^{1}$ It has mostly focused on national-level regulation of banks and non-bank financial institutions, but recently attention has turned to the problem facing regulators when capital is highly mobile.

Section 1 of this note outlines an academic's way of thinking about financial market regulation, or indeed of any type of regulation of markets. The starting point is that the market is “efficient”, except when there are distortions to the free market. Regulatory policy should be aimed at offsetting these distortions, and restoring this efficient market outcome. There are limitations to this approach to regulation, as I will discuss. In the end, academics take this approach because experience suggests it will lead to the best outcomes and it highlights the harm that excessive or misguided regulation can cause to the economy.

Section 2 describes the types of financial market distortions that concern policymakers in the current environment. First is the problem of bubbles or waves of optimism in financial markets. While economists are loath to admit that these exist, recent experience has made it hard to deny these imperfections. But bubbles generally arise and cause problems only in the presence of other

\footnotetext{
${ }^{1}$ See, for example, Borio, 2004, and Evans, et al., 2000.
} 
distortions. The discussion then proceeds to the phenomenon of "overborrowing”. Even if firms and households are completely rational in their financial market decisions, there may be a tendency to borrow too much. Specifically, the debt these units acquire may be individually rational, but collectively excessive. This section closes by discussing the special role that banks and other financial institutions play in the economy. The failure of one of these institutions imposes costs on the economy that go beyond the costs borne by the stakeholders in the firm.

Section 3 builds on the more abstract ideas in the previous two sections to explain why controls on capital inflows might be desirable. Specifically, they might help keep an economy from borrowing too much in cases where regulation of domestic financial markets is insufficient. While the main focus here is on prudential capital controls - controls that may reduce the risk of financial crisis - this section also discusses other rationales for limiting capital inflows. Capital account restrictions increase the country's ability to influence real exchange rates. These goals might reinforce the objectives of prudential policy, or they might work against them.

Section 4 turns to the problem of how global markets impinge on the effectiveness of regulation of domestic financial markets. Domestic regulators might not have as much control over foreign lenders and foreign financial institutions operating within domestic borders as they do over domestic institutions. This section considers how Basel III proposes to deal with this problem.

Macroprudential policies are not the only tool in the policymaker's toolbox that can deal with distortions in financial markets. The policymaker can dust off tools after the fact of a crisis - bailouts, and takeovers of failing banks. In addition, monetary policy can be used as a prudential tool and there is a role for foreign currency reserves. Section 5 briefly discusses each of these tools.

\section{How economists think about regulation}

The starting point for an academic discussion about regulation is the notion of "efficiency". An important theorem in economics says that a certain idealized economic system will achieve "Pareto optimality" or efficiency. This theorem says that the outcome of the market cannot be improved upon, in the specific sense that policymakers could not possibly improve the welfare of one economic agent under the market outcome without reducing the welfare of another. This theorem does not say that the market delivers the best possible outcome. Indeed, it might be the case that a policymaker feels the outcome of the market is unjust, and will need to implement policies that help out certain segments of society. The theorem simply says that any policy that interferes with the 
outcome of this (idealized) market to help one group of people must necessarily make things worse for at least one other person.

This idealized market to which the theorem applies is nothing like the real world. It assumes, first, that all markets - markets for goods, for labor, for assets - are perfectly competitive. That means that no market player is large enough to influence the prices of goods, labor or assets. Of course this condition is not met in the real world because in most markets, firms can set the price of their products; many people have power to negotiate their wage; and, some financial market players are large enough to influence asset prices.

The idealized market assumes there are no "externalities”. An externality arises when the actions of one economic agent influence the choices that another agent can make. For example, a firm that pollutes the river reduces the catch of the fisherman. The problem here is that, in a sense, markets fail because there is no established market for the right to pollute the river. Nobody owns the river, so there is nobody to impose a fee on the polluter for his actions. If the fishermen could collectively enforce a penalty on polluters, the market would work efficiently.

“Pecuniary” externalities arise when the actions of some market participants influence the constraints facing other economic agents through their effect on prices. These pecuniary externalities can arise even in an efficient market. For example, if people decide one morning that they would prefer to watch tennis instead of soccer, ultimately that choice will raise the wealth of tennis players and reduce that of soccer players. The existence of pecuniary externalities does not destroy the Pareto optimality of markets. But when there are other distortions present in a market, policymakers will need to be concerned about pecuniary externalities. In particular, we will see in the next section that “overborrowing” might occur because economic actors do not consider the role that their actions play in leading to asset price collapses.

As the example of the river polluters hinted at, “missing markets” are a general source of inefficiency for market outcomes. There are many economic activities for which no market or market price exists. Important cases of missing markets occur when there is imperfect information in the market and moral hazard. For example, one might want to buy insurance for future income. There may be some unexpected event in the future that reduces one's earnings lower than currently expected. However, that insurance is not available. The problem is that if somebody insured a person's future income, there is no way they could observe how much effort that person was putting in to earning a high income. Their information about effort is imperfect. The insured worker would have the incentive to shirk and not work so hard. 
This type of information problem means that there are real-world practical limits on the types of financial assets that can be sold. The repayment on a loan, for example, ideally might be made contingent on factors that affect the success of the business - the state of the economy or the local market, or other factors beyond the business's control. However, if a business does badly, the lender cannot say for sure whether the failure was due to poor conditions or low effort on the part of the manager. So, usually the interest charged on a loan does not depend on the success or failure of the firm - it is not "state contingent" - it does not depend on the state of the economy or other external factors that face the firm.

Another problem is that some economic agreements are not fully legally enforceable. A household might take out a loan with a promise to repay the loan with interest. However, if the borrower defaults on the loan, usually the lender cannot get back the full value of what was promised. This lack of enforceability is what drives lenders to require collateral for loans.

As we will discuss in the next section, a combination of these types of market imperfections means that the real-world market outcomes are not necessarily efficient. The theoretical prescription in these cases is to use policies that counteract the distortion in the market, and lead us back toward the idealized conditions. In some cases, it is easy to see what the right policy should be. In the case of the firm that pollutes the river, there should be a tax imposed on the firm that depends on the amount of the pollution. The tax should be set so that the polluter bears the societal cost of pollution. If each gallon of pollutants dumped in the river reduces the value of the fishery by $\$ 10$, then a tax of \$10 per gallon of pollutant should be imposed.

The general idea is that it is desirable to implement a policy that directly deals with the market distortion. However, unlike the pollution case, in many instances it is not possible to design a policy that directly reduces or eliminates the distortion the policymaker is concerned with. Or maybe a policy can eliminate one distortion, but at the cost of introducing another distortion. In financial markets, this dilemma appears everywhere.

Consider banks. The institution of banking exists as a market solution to deal with problems of information and incomplete markets. There are lenders (or depositors) that would like to hold liquid assets and are willing to accept a low return without much risk. The role of banks is to recycle those assets to long-term borrowers such as firms that are undertaking risky projects. The bank provides both the service of taking on the risk of maturity mismatch, and of gathering the information necessary to assess the riskiness of different borrowers. 
The possibility of bank runs exists. Depositors could collectively lose confidence in the bank and demand their deposits. That could lead to a bank collapse when the bank cannot raise enough funds to meet the demands of its depositors by liquidating these long-term loans before their maturity. Bank runs make all of the actors in the market worse off. The depositors lose their liquid asset and the borrowers lose their source of long-term loans. The owners of the bank go bankrupt. Still, bank runs can occur because from the viewpoint of the individual investor, it is rational to withdraw deposits when the market is losing confidence in a bank. There is a role for policy to help eliminate bank runs, and that is why deposit insurance was introduced.

However, like any insurance, it raises the moral hazard problem. When depositors are fully insured, the banks have less incentive to act carefully. They might put less effort into evaluating the riskiness of borrowers and take on an excessively risky portfolio, knowing that depositors are not really monitoring the riskiness of the bank's lending. When banks take on too much risk, there is an increased probability of a financial crisis. So the deposit insurance that is meant to deal with one sort of market inefficiency may lead to a different type of problem.

This is an example of what might happen in what we sometimes call a "second best" world. In the idealized world, the policymaker has one policy tool for each distortion, and can calibrate each of those tools exactly so that all of the distortions are eliminated. In the real world, there are more distortions than tools, and the tools can deal only imperfectly with the distortion. When a policy is implemented to ameliorate one problem, it may make another problem worse.

This does not mean that policymakers should not interfere in markets. Clearly the financial system is stronger with deposit insurance (for example) than without, even though deposit insurance leads to riskier behavior on the part of banks. However, this kind of consideration should lead policymakers to be cautious. The unintended consequences of market interference are often quite large and hard to predict, and it is certainly the case that regulation can potentially do more harm than good.

Academic economists tend to favor cautious steps when policymakers intervene in markets. They ask policymakers to pinpoint the distortion in the market that they are concerned about, and they advocate policy tools that are narrowly tailored to deal with the distortion. However, there really is no economic theorem that demonstrates in a "second-best" world that policies narrowly designed to ameliorate a given distortion are necessarily best. Instead, academic economists arrive at this conclusion based more on experience. 
There are two concerns. First, even well-intentioned market intervention can be overly intrusive. Policymakers and planners cannot foresee all of the consequences of their actions, so overly planned and regulated economies tend to be less productive and yield less favorable outcomes. Second is the problem of nepotism, cronyism, favoritism and corruption. The greater the number of layers of regulation, taxes and subsidies, the greater is the scope for this type of problem.

As a result, academic economists tend to treat markets as innocent until proven guilty. Section 3 stresses that while there may be some gains for modest capital controls, we should be wary about imposing them on a large scale. On the other hand, the financial system clearly has been found guilty in the 2007-2009 global financial crisis, and the case for macroprudential policies is strong. It is in the interest of central bankers from all countries to coordinate a comprehensive set of macroprudential regulations for banking and non-banking financial intermediaries.

There is one final point. If an outcome is efficient, it does not mean it is necessarily a desirable outcome. The markets might reach an efficient outcome in which one percent of the population earns ninety percent of the income. Such an economy may have no distortions, but still most people would not think this outcome is desirable. (Perhaps a philosopher could defend a theory of just distribution in which the rich deserve their riches, but there is nothing in standard economic theory that forces us to accept that kind of philosophy.) So efficiency is not everything. Assuming income redistribution is an important concern for policymakers, economists want the policymaker to redistribute in the least distortive way.

\section{Financial Market Distortions}

There is an extensive academic literature on distortions in financial markets. Three types of potential problems have gained prominence in the discussion of macroprudential regulation under high capital mobility - asset market bubbles, overborrowing, and banking externalities. Also, another distortion - currency misalignment - is relevant to the discussion.

\section{Bubbles}

A lot of the discussion of the global financial crisis makes reference to bubbles in the housing market, the stock market and other financial markets. Economists are reluctant to point toward bubbles as the underlying cause of the problem, if by bubbles we mean "irrational exuberance" (in Alan Greenspan's famous phrase). It is difficult to tell whether run-ups in asset prices are caused by too much optimism, or arise because of distortions in financial markets that lead investors to take on too much risk. Even justifiable optimism can lead to problems in the presence of distortions. 
It is sometimes argued that irrational exuberance cannot be a cause of financial market crashes because there are plenty of rational investors who will work on the other side of the market to stabilize asset prices at fundamental values. For example, stock prices cannot be bid up too high because the short sellers will weigh in to drive values back down. This viewpoint does not deny the presence of irrational investors, but takes the view that they cannot drive market prices. Indeed, ironically, in an efficient market they do no worse on average than any other investor. In an efficient market, no investment strategy - good or bad - will earn, over the long run, excess or deficient riskadjusted profits.

However, an army of rational investors might not be standing ready to drive asset prices back to their fundamental value. De Long, et al. (1990) argued that risk aversion restrains investors from taking large arbitrage positions, so that irrational investors can influence asset prices. Moreover, financial constraints for individual borrowers may prevent them from taking large enough positions to offset these exuberant speculators. That is, lenders may be unwilling to finance the large open positions that it would take to battle the bubbly investors. Also, it may be difficult for rational investors to tell whether a run-up in asset prices is justified by fundamentals, or a bubble. A skeptical investor may see rising prices and suspect a bubble, but might also wonder whether the increase is being driven by some fundamental process that the enthusiastic investors are better informed about.

In addition, rational investors may simply not have the information necessary to make smart bets in financial markets. The crisis was precipitated in part because markets did not know a lot of what was necessary to evaluate the risk of certain derivatives, nor the financial health of some institutions. Collateralized debt obligations were mispriced because the originators of home loans in the U.S. were able to disguise the financial health of the borrowers; and, investors put too much reliance on credit rating agencies whose methods could be gamed by lenders and who, in any event, did not seem equipped to evaluate complex baskets of loans. There was too much opaqueness in markets, so that investors could not judge the financial health or risk positions of many financial institutions, including those such as AIG that took enormous uncovered positions in the credit default swap market.

It is hard to ignore the long history of financial market crises that Reinhart and Rogoff (2009) document. As they note, "No matter how different the latest financial frenzy or crisis always appears, there are usually remarkable similarities with past experience from other countries and from history. (p. xxv).” Shiller (2000) has noted a long history of stock market booms and busts that are difficult to attribute to anything other than waves of excessive optimism. As Persaud (2009) says, “The last 84 
crises occurred without credit default swaps and special investment vehicles. The last 80-something had nothing to do with credit ratings." He notes that “one of the key lessons of this crisis is that market discipline is little defense against the macro-prudential risks that come with the economic cycle.”

\section{Currency Misalignments}

Even when there are no bubbles and asset prices correctly reflect the risk-adjusted expected present value of returns, asset price fluctuations can magnify other economic distortions. One case, discussed in Engel (2009, 2011), arises when nominal prices and wages are sticky. In that case, exchange-rate movements can distort relative prices across countries. For example, if European prices and wages are set in euros and adjust slowly, while American prices and wages are set in dollars, then an appreciation of the dollar is beneficial to European producers and exporters. The euro value of their dollar sales in the U.S. rise, and their wage costs fall relative to those of their American competitors. In an efficient economy, European producers should gain an advantage, for example, when their current productivity rises; but, in a floating exchange rate system with sticky prices, the euro appreciation can occur for a number of reasons. Expectations about future monetary policy or financial constraints can strengthen the euro, and give the European firms an advantage. In these cases, the exchange rate change distorts incentives, because European producers are encouraged to expand even though they have not enjoyed any productivity gains or change in tastes that increase demand for their products.

\section{Overborrowing}

Another important case in which asset prices send misleading signals even though there are no bubbles is the case of overborrowing. ${ }^{2}$ Insufficient macroprudential regulation can lead lenders to offer interest rates that are too low, encouraging overborrowing. The levels of borrowing may be entirely rational from the perspective of the individual agents - that is, firms or households - that do the borrowing. However, from the standpoint of the welfare of the economy as a whole, there is too much debt. There is an externality because the individual agents do not take into account how their borrowing will influence the economy as a whole. Because of insufficient regulation, they do not bear the cost they impose on society, just like the firm that pollutes the river described above.

Here is the problem the academic literature has pinpointed: Suppose that there is an economic downturn that could start for any number of reasons - an energy shock, a fiscal contraction, etc. As the downturn begins, there will naturally be a decline in asset prices. This will adversely affect the

\footnotetext{
2 This subsection relies on the recent expositions of Korinek (2011b) Jeanne, et al. (2012), and Jeanne (2012), as well as the more technical work of Korinek (2011a), Bianchi (2011) and Bianchi and Mendoza (2011, 2013).
} 
balance sheets of firms, households, and financial institutions. The value of collateral will fall.

Because of this, firms and households will cut back on spending. Firms may reduce investment, both in light of the downturn but also because they are considered a greater credit risk (due to weakened balance sheets) and so are less able to borrow. Household wealth has declined, and they also are less able to borrow due to the reduction in the value of their assets. In addition, as the value of assets held by the banking system decline, the banks are more reluctant to extend loans. The decline in demand intensifies the economic downturn, which magnifies the decline in asset prices. A downward spiral of asset prices and economic activity may ensue.

A similar sort of spiral may emerge when there is a currency mismatch between collateral and the denomination of loans. Suppose a domestic firm or household borrows from a foreign bank in a loan denominated in foreign currency. There may be some event that sets off a depreciation of the domestic currency, such as a downturn in domestic activity. This will reduce the access to credit of firms and households, further reducing aggregate demand and accelerating the downturn. Again, there is a feedback loop as the decline in the economy magnifies the currency depreciation. As the currency depreciates, the domestic currency value of the loan increases, and firms and households, or financial institutions that have borrowed abroad, find it increasingly difficult to meet their obligations. This spiral has also affected the ability of governments to repay sovereign debt as well. Their tax base narrows as the economy contracts, but the domestic currency value of the debt expands.

The problem here is that each economic agent rationally reduces demand and debt when the initial downturn sets in. They do not take into account how their actions feed back into asset prices. From the individual's standpoint, they should not factor this into their calculations, because each firm or household is too small to have a measurable effect on asset markets. However, the actions of all the economic agents together drive down asset prices, setting off the negative cycle. This describes a “pecuniary” externality (see section 1 above), in that the effect of one agent's actions on the rest of the economy works through prices. In a perfectly competitive market, pecuniary externalities are not distortionary. They are simply the market's mechanism for equilibrating supply and demand. Here, the problem arises because financial markets are constrained. The amount of loans that firms and households can obtain depends on the state of their balance sheets and the value of collateral they can put forward. While a recession should drive down asset prices in an efficiently operating economy, when collateral and balance sheet constraints are present, the drop in asset prices leads to a credit crunch. A simple recession can be magnified as these financial constraints become more and more binding. 
By extension, private agents also tend to take on too much risk. The externality arises because borrowers need to sell assets during downturns in order to make required payments, but this causes declines in asset prices. Borrowers would have less need to sell assets if they held portfolios that were better insured against downside risk. They hold too few assets that pay off during bad times, either in the form of explicit insurance (such as options or credit default swaps) or in terms of more diversified portfolios. From the perspective of society as a whole, these portfolios are too risky.

It is also true that private borrowers, businesses and financial institutions may be encouraged to take on too much risk by the very assurance that central banks and other macroeconomic policymakers stand ready to cushion the impact of the worst outcomes. The moral hazard problem that exists with the provision of any insurance may indeed lead to overborrowing and help contribute to a run-up in asset prices.

\section{Banking Externalities}

Banks and other financial intermediaries play a special role in the economy. Bank failures have consequences beyond the banking sector. If banks fail, the system is no longer able to play its role of channeling funds from depositors to borrowers. As we have seen, a failure in the banking system may lead to a credit crunch. Firms cannot obtain funds to make profitable investment. Moreover, when borrowing and lending are shut down, aggregate demand declines, which can lead to a recession and unemployment. Persaud (2009) says, "It seems banal today to point out that the reason we try to prevent financial crises is that the costs to society are invariably enormous and exceed the private cost to individual financial institutions. We regulate to internalize the externalities in these institutions."

There is a connection between the goal of preventing overborrowing and of keeping a sound financial system, but they are not exactly the same thing. The phenomenon of overborrowing and fire sales of asset prices are one way in which the banking system can become endangered, but it is not the only one. The various problems that can arise in the banking system and the types of macroprudential policies that are desirable are the subject of an extensive literature. ${ }^{3}$ On the other hand, stabilizing the domestic banks and non-bank financial intermediaries does not necessarily eliminate the problem of overborrowing. It is this concern that motivates the case for capital controls.

\footnotetext{
${ }^{3}$ For two recent surveys, see Bank of England (2011) and Galati and Moessner (2013).
} 


\section{Capital Controls}

There is a case to be made for including capital controls in the toolbox of the macroprudential regulator. On balance, limited use of capital controls can help alleviate some of the market distortions discussed in the previous section, such as overborrowing. ${ }^{4}$ In addition, capital controls can help policymakers limit exchange rate fluctuations, which may or may not be considered a macroprudential policy. However, the case for capital controls comes with important caveats - they may not work well and not for long, they may have unintended distortionary consequences, and they may encourage corruption and favoritism by government officials.

"Capital controls" refers to measures to influence capital flows that are based on residency. ${ }^{5}$ For example, Brazil's recent tax on capital inflows applies to foreign investment in the Brazilian economy. This is an example of a market-based control because the tax increases the cost of the flow to the investor. It can be contrasted with administrative controls, such as measures that bar or limit foreign purchases of domestic assets. ${ }^{6}$ Related to capital controls are macroprudential measures that do not discriminate explicitly on the basis of residency but are aimed, in part, at influencing inflows.

\section{Why capital controls?}

The first point to be made is that in an interconnected world with high capital mobility, policymakers cannot optimally reduce the chances of financial crisis if they can only regulate domestic lenders. Stabilizing the domestic financial system is an important goal, but it is not enough to prevent excessive debt accumulation by corporations or households. That is because borrowers can borrow directly from foreign banks, or from domestic subsidiaries of foreign banks for whom domestic prudential regulation is less binding. (For more on this latter point, see section 4.) Obstfeld (2012) examines recent evidence on international capital flows in high income and emerging markets, and concludes "recent experience shows that gross international asset and liability positions furnish the key conduit through which financial meltdown is transmitted and amplified.”

To quote Jeanne, et al. (2012):

Capital controls may fill some gaps in domestic macro-prudential regulation (Ostry et al., 2012). The official sector and international bodies (the Basel committee and the Financial Stability Board) have adopted a rather restrictive view of macroprudential regulation, which is reduced to the introduction of counter-cyclical elements in the capital adequacy regulation of banks. However, the logic behind macroprudential regulation should apply to all financial flows in the economy (including

\footnotetext{
${ }^{4}$ See Jeanne and Korinek, 2010.

${ }^{5}$ See Habermeier, et al., 2011.

${ }^{6}$ See Jeanne, et al., 2012, for more on this distinction.
} 
mortgages in the household sector or the choice between debt and equity finance in the corporate sector) and not only those intermediated by banks. In particular, the corporate sector can borrow abroad on its own account without going through domestic banks. The macroeconomic impact of capital controls may be more broad-based and far-reaching than that of banking regulation. From this point of view, one could argue that prudential capital controls should be viewed as one of the tools of macroprudential regulation in open economies.

Currency mismatch is another reason to invoke capital controls as an additional instrument. Certainly many countries, including notably Asian countries in 1997-1998, have faced the spiral associated with depreciation, deteriorating balance sheets, and recession. Foreign currency loans largely come from foreign lenders, and so capital controls can help reduce this currency mismatch. In fact, one important form of control involves limits or taxes on foreign currency borrowing.

\section{What flows should be targeted?}

Korinek (2011b) and Jeanne et al. (2012) explain that capital controls should be specifically targeted toward types of investment that increase macroeconomic risk. First, capital controls should be on inflows, since the distortion arises from overborrowing.

They should be heavier on assets that contribute more to systemic risk. Debt flows should be more controlled than equity flows. Short-term debt is a bigger concern than longer-term debt. In general, there is much less systemic risk with foreign direct investment. Ostry, et al. (2010) provide a similar hierarchy: foreign currency debt; CPI indexed local currency debt; local currency debt; portfolio equity; and, FDI. The concern about foreign-currency debt is also emphasized by Korinek (2011a), exactly because of the problem of currency depreciations that accompany sudden stops in international lending. Ostry et al. also find, empirically, that countries with more financial FDI were more vulnerable in the 2007-2009 crisis. They speculate that financial FDI might reflect lending from a parent bank to a local branch or subsidiary, so that it is more like portfolio flow than FDI. In that case, it should rank higher on the list of investments that should be subject to capital controls than other types of FDI.

All of these studies emphasize that controls should be countercyclical. They should be increased during booms and reduced during downturns. ${ }^{7}$ Indeed, Korinek (2011a,b) makes the point that in practice during downturns, capital flows out, so controls on inflows would have little bite. But during periods of hot money inflow, it is important to raise controls to prevent excessive borrowing. Korinek (2011a, 2014), Bianchi (2011), and Unsal (2013) are all attempts in the context of

\footnotetext{
${ }^{7}$ See Benigno et al. (2014) for a macroeconomic model that demonstrates the desirability of macroprudential capital control measures.
} 
macroeconomic models to assess the optimal size of controls, or the optimal tax on capital inflows, but the research in this area is still in its infancy. ${ }^{8}$ The studies all indicate that the controls or taxes should be relatively modest - nowhere near large enough to cut off capital inflows entirely.

\section{Capital controls and exchange rate targets}

Capital controls can also play a role that is not macroprudential, in that they do not target systemic risk, but nonetheless reduce macroeconomic volatility. In particular, capital controls can help to reduce exchange-rate volatility. Capital controls might directly reduce the magnitude of rapid appreciations of the currency when there are hot money inflows. Many countries, such as Brazil beginning in October 2009, have imposed controls on inflows to combat currency appreciation.

Indirectly, capital controls give policymakers scope for using sterilized intervention to influence exchange rates. There is near consensus that sterilized intervention is unlikely to be successful except over very short horizons when capital can flow freely, because any central bank intervention can easily be swamped by private capital flows. Without some policies to slow down capital flows, only unsterilized intervention can influence exchange rates, which would mean that monetary policy shifts focus from inflation stabilization to exchange-rate stabilization. De Gregorio (2011a,b) remarks that in order to maintain credibility, central banks should stay focused on inflation stabilization and use sterilized intervention to influence exchange rates. Schmitt-Grohe and Uribe (2012) and Farhi and Werning (2012) argue that even within a currency union, some aspects of selforiented monetary policy by member countries could be maintained by using time-varying capital controls to influence the effective interest rate within each country.

There is a rationale for targeting exchange rates based on efficiency considerations. As mentioned above, when exchange rates fluctuate, they influence relative prices and wages across countries because nominal wages and prices do not adjust as fast as exchange rates move. Of course, if foreign exchange markets are gripped by bubbles or waves of optimism, exchange rate movements can be distortionary. But even if foreign exchange markets are efficient, the fluctuations of exchange rates do not lead to efficient movements in international wages and prices.

Take the example of the strong appreciation of the dollar when Lehmann Brothers failed. The dollar strengthened probably both because it was considered a "safe haven" and because there was an increase in demand for liquid dollar assets. The appreciation, in other words, stemmed from financial market considerations. But it also was a windfall gain for German manufacturers at the expense of American firms, even though German firms did nothing (such as increasing productivity) to justify

\footnotetext{
${ }^{8}$ See Korinek (2011b).
} 
these windfall gains. Nominal exchange rates are influenced by expectations of the future, including expectations of monetary policy and financial market conditions, and influenced by risk, all in ways that do not lead to optimal changes in international relative prices and wages. If global markets are to allocate resources efficiently, then prices should reflect underlying resource costs (costs of labor, technology levels, efficiency in production, etc.) The competitiveness of firms should not depend on the nominal exchange rate. A currency is misaligned when the exchange rate moves to a level where a country's competitiveness in world markets is altered.

Limiting fluctuations of the exchange rate to prevent temporary currency misalignments, then, is a legitimate goal of policy. Exchange rates could also be deliberately manipulated in order to achieve a goal for the trade balance or current account. A country that is running an excessive current account deficit could use sterilized intervention to depreciate the currency, with the aim of reducing the deficit. This might well be considered an indirect way of reducing excessive foreign borrowing as a substitute for capital controls or other macroprudential policies. However, I argue at length in Engel (2009) that the exchange rate is not a good tool for controlling trade imbalances. Empirical evidence and macroeconomic theories indicate that in practice exchange rate changes are unlikely to have much influence on imbalances in the short run.

Using sterilized intervention to control exchange rate fluctuations means that policymakers must choose a level of the exchange rate to stabilize around. The guiding principle is to choose an exchange rate that gives neither an advantage nor a disadvantage to their producers. This can be very difficult to implement in practice, and the target would change over time as local wages and other costs change. Berka, et al. (2012, 2014) present empirical evidence that real exchange rates in the Eurozone are closely in line with costs, and in part because the initial conversion rates from local currencies were set properly but also because prices adjust over time to reflect cost changes. The case of the Eurozone countries, though, may not be typical, because these countries share many common economic traits that make it easier to assess the equilibrium level of real exchange rates.

In contrast, there is an ongoing controversy about the Chinese exchange rate. Engel (2009) surveys this issue, and mentions some of the difficulties of calculating an exchange rate that is neutral with respect to the country's competitiveness. Many studies have found the renminbi to be undervalued by this definition, but other studies, using slightly different methods or revised data find the renminbi is not undervalued. Indeed, there is a difference between the desired exchange rate from the perspective of global efficiency and the optimal exchange rate level if each country's central bank acts strategically. If capital controls became widely used as an exchange-rate management tool, there 
may be increasing disputes over "currency wars” in the absence of international coordination of policies. $^{9}$

\section{Effective capital controls vs. distortionary controls}

One cannot meaningfully say that the renminbi is undervalued simply because it would appreciate if there were no intervention by the People's Bank of China, or on the evidence that the PBC is acquiring reserves. However, in cases where it is very difficult to calculate the equilibrium exchange rate, it is plausible to look at the long-run behavior of reserve accumulation to make an assessment. If a country has strong capital controls in place, then it has the power to control real exchange rates for extended periods of time. It can use sterilized intervention to target the nominal exchange rate, and monetary policy to control domestic prices, which in tandem determine real exchange rates. Assume that the policymaker stabilizes the exchange rate to keep real exchange rates and relative prices in alignment with fundamental values. When goods and asset markets are efficient, there is no reason why the current account should be balanced from quarter to quarter or year to year. In fact, a country may run imbalances over long periods of time, but ultimately its net claims on the rest of the world (either positive or negative) should stabilize relative to GDP.

With this in mind, one way to gauge whether real exchange rates are correctly aligned over long periods is whether the central banks holdings of reserves stabilize relative to GDP. Consider a fictional economy that uses controls to eliminate all private capital flows. Then all capital flows go through the central bank, and the goal of stabilizing net foreign assets relative to GDP means approaching a constant ratio of reserves to GDP. This does not mean that the reserves to GDP ratio must be constant over short periods of time, but it should not continue to grow for a decade unless some exceptional circumstances prevail.

In applying this rule of thumb to China, however, one must use caution. After the 1997-1998 Asian crisis, many emerging market central banks increased reserves as a defense against capital flight. China was no exception to this rule. Certainly a significant fraction of the increase in China's reserve to GDP ratio over the past decade can be attributed to this permanent adjustment. This increase may well be justified both on theoretical grounds, ${ }^{10}$ and on the grounds that in fact countries that had high levels of reserves performed significantly better during the global financial crisis. Frankel and Saravelos(2012) undertake extensive empirical analysis of factors that were associated with differential economic performance during the crisis, and conclude “A level of reserves

\footnotetext{
${ }^{9}$ See Heathcote and Perri (2014) for a theoretical analysis of how capital controls may be used strategically to influence the terms of trade.

${ }^{10}$ See, for example, Obstfeld, et al. (2010).
} 
equivalent to approximately 100\% of GDP is associated with a one standard deviation fall in crisis intensity as measured through the exchange market pressure index.” We return to the question of how reserves can be used in section 5 .

\section{Empirical findings on capital controls}

We have summarized here briefly two rationales for capital controls - as macroprudential instruments, and as a means to facilitate exchange-rate stabilization. Now we consider the empirical findings regarding capital controls. ${ }^{11}$

Controls on capital flows have not generally been found to be effective in limiting the size of flows. This is highlighted most recently in the study by Forbes and Warnock (2012) that examines a large cross-country panel of data. The data are on gross flows - inflows and outflows - rather than just net flows. The gross flows are demarcated by whether the owner of the capital is a foreigner or a local resident. They find no evidence that the degree of capital flows has any influence on the size of flows from foreigners during extreme episodes - episodes of capital surges (when foreigners bring large amounts of money into a country) or episodes of stops (when they take money out.) This is consistent with a long line of literature, including the paper by de Gregorio et al. (2000), that finds little effect of capital controls on the size of flows.

Klein (2012) finds little evidence that capital controls can affect exchange rates or growth in GDP. At best, appropriate controls can dampen the occasional large surges of capital inflows. Klein distinguishes between the economic outcomes of countries that have longstanding, broad-based capital controls and those that impose them episodically, only to remove them or reduce them later. While the data appear to show that countries with more permanent controls have slower credit growth, Klein attributes the difference to the fact that those countries are also lower income and presumably less financially developed. His findings imply that episodic controls have little of their desired effect on the ultimate economic outcomes of exchange-rate stability and economic growth.

However, the empirical literature is plagued by a problem that is common to almost all analysis of macroeconomic policies. Policies are implemented in response to economic conditions. Even the best policies do not completely cure economic problems, so the problems will persist even after the implementation of the policy. We then tend to find that economic policies are followed by bad economic outcomes. It is hard to measure the impact of the policies on improving those outcomes. For example, controls on capital inflows are usually implemented when policymakers find a trend of high and increasing inflows. It is almost impossible to measure what would have happened

\footnotetext{
${ }^{11}$ See the surveys of Habermeier et al., 2011, and Magud et al., 2011.
} 
in the absence of controls. We tend to find no relation between the introduction of controls and the pace of inflows, but we cannot conclude decisively that capital controls are ineffective in slowing down inflows.

Forbes et al. (2015) attempt to deal with this problem using a statistical technique called propensity score matching. In essence, the technique compares outcomes in countries with similar characteristics, some of which impose capital controls and others that do not. This method constructs a prediction of whether a country will impose capital controls based on observable economic characteristics. Countries with similar probabilities of imposing controls are compared, but some of these countries in fact do impose controls while others end up not imposing controls. Using this technique, Forbes et al. find that capital controls are generally ineffective in controlling exchange rates or net capital flows. However, there is evidence that they may help achieve some macroprudential goals such as reducing bank leverage and bank credit growth.

In fact, Fernandez et. al. (2014) find little evidence that capital controls in practice have been imposed countercyclically. They examine the policy behavior of 78 countries - high, medium and low-income - that have altered their capital controls episodically, according to the classification of Klein (2012). Over the 1995-2011 period, there is essentially no evidence that these countries tended to increase controls during booms and reduce them during contractions.

There is evidence that controls can tilt the composition of flows. De Gregorio et al. (2000) found that Chilean controls changed the composition of flows toward longer maturity. This finding is confirmed in the recent study by IMF researchers, Ostry et al. (2012). The meta-study of Magud, et al. (2011) finds this to be a robust outcome over many empirical studies. Ostry et al. also find that the currency composition of flows can be effectively altered by policies that discourage borrowing in foreign currencies.

Ostry et al. (2012) find that countries with capital controls rebounded more quickly from the financial crisis than those that did not have controls. They examined the change in economic growth from 2004-2007 to 2008-2009, and found that countries with capital controls did better.

There is mixed evidence on the question of whether capital controls actually allow countries to control real exchange rates and have more independent monetary policy, though the meta-study of Magud, et al. tends to favor this conclusion. Baba and Kokenyne (2011) do not find much evidence that capital controls directly reduce exchange rate pressure, but they do allow central banks more latitude in conducting an independent monetary policy while using sterilized intervention to control exchange-rate swings. 
Chinn and Ito (2006) find that allowing capital inflows does speed the development of local financial markets, especially local equity markets. But there is a threshold effect - this works only in countries that score highly in measures of bureaucratic quality and law and order. An extensive study by Jeanne et al. (2012) finds no evidence that the limited use of capital controls reduces long-run growth.

The studies consistently find that capital control effectiveness diminishes over time. The conclusion drawn by many of these researchers is that over time investors find more ways to evade capital controls.

These empirical findings indicate that capital controls are likely to be most effective when they target short-term investments and foreign-currency lending. Because markets find ways of circumventing controls over time, it is plausible to use them to counter surges in capital inflows during boom times, or to temporarily control exchange rates. This conclusion is consistent with the notion that capital controls should be countercyclical. Modest controls might be imposed on temporary hot money inflows, but removed when the capital inflows cool down.

The interesting recent study by Forbes et al. (2011) investigates the investments of emerging market portfolio funds in response to the capital controls introduced by Brazil in 2009. Their empirical work is supported with interviews concerning the investment strategies of these investors. One point that they emphasize is that when one country imposes controls, it tends to have spillover effects on its neighbors, as funds reallocate investments toward countries without controls. This study also finds that Brazil's tax on foreign investment in bonds had a significant effect on foreign investments in Brazilian equities. Based on the interviews, the authors conclude that this occurred because the funds view capital controls as a signal about the willingness of a country to impose controls in the future, and in general to interject itself into capital markets.

More permanent controls are likely to be counterproductive. There is a deadweight loss when agents expend resources to find ways of circumventing the controls. The longer controls are in place, the more likely will be problems of corruption, or at least favoritism. Longer term controls will make it more likely that policy distorts economic incentives and leads to misallocations, rather than correcting short-term inefficiencies. When controls are in place for long periods of time, real exchange rates may become misaligned and undesirable trends of increasing reserve to GDP ratios may arise as sterilized intervention buys up foreign assets in order to maintain an undervalued currency. 


\section{Macroprudential Leakages}

Temporary capital controls might be a useful tool to maintain financial stability in a world of high capital mobility, but the combination of capital controls and domestic macroprudential regulation still may not be sufficient to achieve the policymakers' desired levels of safety. An important issue concerns the regulation of financial institutions that do business across borders. ${ }^{12}$

In order to impose uniform regulations across all banks (or all financial intermediaries) operating within a country, a national authority must have supervisory power over branches and subsidiaries of foreign banks. Even with this power, there are two potential problems. On the one hand, if the national regulations are effective, foreign financial institutions might leave the country to do business where the regulatory regime is more relaxed. On the other hand, even in the best of circumstances, multinational financial institutions might really not be subject to the same degree of prudential control as local institutions, leaving the local intermediaries at a disadvantage. The solution to this dilemma is harmonization of regulations across countries.

A recent study by Aiyar, et al. (2014a,b) illustrates the problem of “macroprudential leakages” for the case of capital requirements imposed by the Financial Services Authority (FSA) on banks in the U.K. The foreign bank branches that are located in the U.K. are not subject to FSA regulation, but instead to regulation by authorities in the home country of the bank (but subsidiaries of foreign banks are regulated by the FSA.) This study finds that when the FSA has increased regulatory requirements, there are substantial leakages, in that lending shifts from the regulated banks to the unregulated foreign branches located in the U.K.

If those leakages are plugged by some sort of agreement that allows a country to impose its own capital requirements and other macroprudential policies on foreign lenders, it is likely that foreign financial institutions will shift their activities to other countries. In one sense, this is a desirable outcome, because the purpose of the regulations would be to reduce the fragility of the financial system. The effect might be similar to capital controls, in that risky foreign lending is reduced. However, the outcome might be much less desirable than the effects of temporary capital controls. First, countries should welcome well-regulated foreign-based financial institutions within their borders. They might bring expertise that is not available locally, and may help to make the local financial sector more competitive. Moreover, if the foreign-based banks move out, the effect is more long-lasting than would be desirable. The effect would not be the same as the countercyclical capital controls advocated by Korinek (2011 a,b), or Jeanne et al. (2012).

\footnotetext{
${ }^{12}$ See Acharya (2003), Dell’Ariccia and Marquez (2006), Jeanne (2013), Bengui (2014) and Kara (2014) for theoretical analyses of the international competitive aspects of macroprudential policymaking.
} 
Basel III attempts to deal with this issue by introducing "reciprocity". The home country of an international bank, under these provisions, will impose a capital buffer that is a weighted average of the capital requirements in the host countries where the banks operate, where the weights are determined by the share of the bank's exposure in different countries. For example, a bank that has half of its exposure in its home country, and half in one other country will face capital requirements equal to the average of the two countries' required capital ratios - subject to the provision that the requirements will not be lower than those imposed by the home country on fully domestic banks. Reciprocity becomes binding when some countries decide to impose stronger requirements than the minimum recommended in Basel III.

While this requirement may help to alleviate the problem of leakages, consider the analysis by the British law firm Shearman and Sterling (2011): "In practice it would seem to (i) create an economic incentive for banks to increase their exposures to countries with no (or a relatively smaller) capital buffer requirement in place and to reduce their exposures to countries that have imposed a relatively larger buffer, and (ii) add to the complexity (and compliance burden) associated with the calculation of the buffer." That is, the analysis suggests that banks will be motivated to shift their operations toward countries with lower capital requirements, if the higher capital requirements are binding.

Here is an example of the problem: Suppose that there is some global event that regulators in a country are worried about for which banks need an 8\% capital/asset ratio to be protected. The regulator might set the ratio in his country at $8 \%$, but regulators in other countries might set their rate lower, at say 6\%. Perhaps that is because they are subject to extensive lobbying by the financial industry, or perhaps the cost of bailout policies in the event of a crisis is lower in those countries. Now consider a bank that has branches in ten different countries with equal exposure in each, including the one with the $8 \%$ ratio. If it held the minimum required capital, it would have a ratio of 6.2\%. Even though the prudent country imposed an 8\% ratio, the bank is not protected against the global event. That bank would fail, and the failure of its branch could have important systemic consequences in the country with the prudent regulation.

Greater macroprudential regulation does reduce the exposure of the country to undercapitalized international banks, but may not be sufficient to alleviate the problem. Capital controls, combined with the macroprudential policy, can lessen the problem even more. But it might take extensive capital controls to reduce the presence of the branch of the foreign bank to where it no longer presents a systemic risk. A combination of capital controls and macroprudential regulation 
could achieve this goal, but the outcome might be far from the preferred outcome that would arise if the global bank were required to hold sufficient capital. It would be better to have adequately capitalized foreign banks operational in the market, bringing in their expertise and efficiency, but one country’s regulation alone can merely reduce the exposure of undercapitalized foreign banks.

The problem could be avoided, of course, if regulatory requirements were the same across all countries. The Basel agreements indeed exist precisely in order to harmonize banking supervision internationally. However, Basel III aims to get all countries to adopt a set of minimum capital requirements. Optimal macroprudential policies are probably not the same for all countries. The next section discusses how “after-the-fact” policies - monetary policy, bailouts, and reserve expenditures should be part of the optimal policy mix, in addition to prudential policies. It is likely that emerging markets are more constrained (relative to high-income countries) in using these ex post policies. In that case, they should have stronger macroprudential regulation.

Emerging market regulators might want to impose stronger conditions - larger capital buffers, stricter maximum leverage ratios, stronger conditions on the types and amounts of assets that banks can hold, stricter requirements on over-the-counter derivatives, etc. - than high-income countries end up settling on. If the emerging market regulators attempt to impose these requirements on their domestic financial system, they face a reduction of activity in domestic markets by global financial institutions, and put domestic financial institutions at a competitive disadvantage.

On the other hand, emerging market countries may be particularly vulnerable to lack of access to capital in global markets in a general environment of increasing regulation. When home-country capital requirements increase for large financial institutions, one can expect a general reduction in lending. Aiyar et al. (2014c), however, find that the reduction is not uniform. International lending tends to decline, and the pattern of decline is itself not uniform in that banks tend to favor their most important country relationships while more drastically reducing lending in other countries.

\section{Ex Post Policies}

Macroprudential policies could avoid all financial crises, but at a very high cost to the ability of the financial system to do its job of intermediation and risk sharing. Ex post policies - policies that are implemented when a financial crisis arises - must remain part of the policymaker's toolkit. ${ }^{13}$

Monetary policy is an important tool that can be used during a financial crunch. While, as de Gregorio (2011 a,b) emphasizes, it is important that central banks not abandon their inflation target, in

\footnotetext{
13 This point has been made recently in theoretical economic models by Benigno et. al. (2013), Jeanne and Korinek
} (2013), and Bianchi (2013). 
fact in practice there may not be a conflict between the goals of monetary easing and inflationtargeting. Economic contraction and disinflation are the usual consequences of a financial crisis. Inflation targeting during these episodes may require policies that raise the inflation rate. Monetary easing may help to reduce credit constraints, but also will reduce the risk of deflation.

Bailouts may be necessary during a financial crisis. Many critics of the Federal Reserve’s policies in 2007-2009 say that the Fed created moral hazard by bailing out the financial system. Indeed, it seems likely that financial institutions may have increased the riskiness of their portfolios because they believed that the Fed would bail them out in the event of a systemic event. The bailout arises in the form of easier monetary policy and more directly in the form of loans from the Fed to the banking system as the Fed played its role of lender of last resort. If this was anticipated, then indeed expectations were fulfilled.

However, moral hazard cannot be an argument against a central bank performing its duty in the event of a crisis. If the central bank did nothing, the financial system could fail drastically. The threat of that failure certainly would send the message to banks to be more prudent, though the incentives to take on excessive risk would still exist. Saying the central bank should step back and do nothing because of moral hazard is like saying that markets for auto, home, or health insurance should be shut down because of moral hazard. As was discussed in section 1, imperfect information about the actions of the insured introduces distortions into private markets. There will be under-provision of insurance. In the case of financial institutions, that under-insurance leads to a risk borne by the economy as a whole that is not fully internalized by the financial system. Central banks provide insurance, knowing full well that it creates moral hazard. There is some optimal tradeoff between the amount of insurance they provide and the amount of moral hazard they create. Macroprudential regulation is one tool that works to reduce the moral hazard problem.

Many commentators and researchers argued before the crisis that accumulation of foreign exchange reserves by central banks was wasteful and ill-advised. It was said that central banks accumulated far more FX reserves than was necessary to fend off an attack on their currencies, and that the reserves earned low rates of return compared to other investment opportunities.

Since the crisis, opinions have changed. According to the evidence of Obstfeld et al. (2009) and Frankel and Saravelos (2012), countries with a large war chest of foreign exchange reserves weathered the crisis relatively well - better than countries with low levels of reserves. Obstfeld et al. (2010) reassess the stock of reserves needed to defend a currency. When the central bank is the lender of last resort, it may need to amass a large stock of reserves to defend the currency. In order to 
prevent a run on banks and subsequent flight to foreign currency, the central bank holds reserves. Its potential liabilities include the bank deposits that could be converted to foreign currency. By maintaining a large stock of foreign exchange reserves, the central bank signals that it will be able to defend the currency, and it can therefore discourage a bank run from occurring in the first place. Ghosh, et al. (2012) provide some evidence that countries that hold high levels of reserves are motivated by the desire to hold insurance against capital account shocks.

Engel (2009) notes that during the global financial crisis, the role of foreign exchange reserves in emerging market countries was markedly different than it had been in past crises that originated in the emerging markets. In these previous crises, emerging-market countries had accumulated debt denominated in foreign currency (U.S. dollars, mainly). The crises led to steep depreciations of their currencies, and an increase in the value of their external debt in units of their own currency.

The global financial crisis, which had its epicenter in the U.S., led to an appreciation of the dollar in the months immediately following the collapse of Lehmann Brothers. But the U.S. had also borrowed primarily in dollar terms, so the appreciation did not reduce the external value of its debt in terms of dollars. Still, the emerging markets needed foreign currency reserves to defend their own currency. The dollar appreciated because banks and other financial institutions in the U.S., Europe and other high-income countries, especially, wanted to protect their balance sheets and hoarded dollar assets. Dollar liquidity dried up, creating an excess demand for the dollar, driving up its price. The central banks of emerging market countries used reserves to protect their currencies, and they needed specifically dollar reserves in order to protect their currencies against this peculiar dollar drought. Other forms of reserves - euros or SDRs - probably would not have been as useful during this crisis.

The currency swaps offered by the Federal Reserve during the current crisis altered the picture. Obstfeld et al. (2009) demonstrate that in cases where central banks did not hold large dollar reserves, the availability of the swap lines apparently had a significant effect in stabilizing exchange rates. On the other hand, many Asian countries already held large and adequate stocks of reserves, so the availability of the swap line was more symbolic. The role that these swap lines played does demonstrate the importance of having access to a large store of reserves, but may also demonstrate that there is less need to hold reserves if the swap lines are available. However, Obstfeld, et al. (2009) make two observations. First, the scale of the lending to central banks that was necessary in this crisis was so large that it is difficult to imagine any other institution providing such a large supply of dollars save for the institution that can create that currency - the Federal Reserve. These authors note that some central banks such as China's do have very large holdings of foreign exchange reserves, but it 
would take an extraordinary commitment for these banks to lend their reserves in a crisis. The size of the swap lines under the Chang Mai initiative may not yet be sufficient to deal with the next crisis. Second, this was an extraordinary event. We have no way of knowing whether the Fed would be willing to create such enormous swap lines in the future.

Some have claimed that the U.S. and the other high-income countries have been hypocritical in their policy recommendations. While they discouraged Asian countries from following expansionary monetary policies and undertaking large bailouts of banks during the 1997-1998 crisis, these are exactly the policies they implemented in their own homegrown crisis of 2007-2009 that we call the global financial crisis. However, a key difference is that external debts of U.S. and European firms, households, and governments were primarily denominated in their own currencies. When a country's debt is denominated in foreign currency, the scope for monetary expansion and bailouts is much more limited. Those policies are likely to lead to currency depreciation, which then increases the debt burden in local-currency terms. Even if governments have issued debt only in their own currency, bailouts mean that to some extent private debt is a liability of the body of taxpayers as a whole. A depreciation will increase the local-currency value of debt that needs to be redeemed by the central bank in its role of lender of last resort, and there could then result a vicious downward cycle more bailouts leading to more depreciation, requiring more bailouts. ${ }^{14}$

It is conceivable that bailouts could appreciate the currency, though there is no empirical evidence to support this contention. The argument is that by rescuing the banking system, the bailout restores the confidence of investors who then put more faith in the currency. As has already been noted, the U.S. dollar did appreciate during the early months of the crisis, but this likely occurred not so much as a vote of confidence in U.S. policymakers, but rather as a result of dollar hoarding that arose from an increase in demand for dollar liquidity.

We have come full circle now. Because central banks of emerging markets are less able to use monetary policy and bailouts in the event of a crisis, they have incentives to use different tools than policymakers in high-income countries. They may consider countercyclical capital controls, particularly to discourage excessive short-term and foreign-currency borrowing. They may amass more foreign exchange reserves (individually and as part of regional arrangements) as a way of preventing a downward currency spiral in the event of a crisis. And, they may advocate for stricter global macroprudential regulations than heavily-lobbied high-income country regulators prefer.

\footnotetext{
${ }^{14}$ Indeed, in this respect, Greece has benefitted from having been able to issue debt in euros.
} 


\section{Conclusions}

Academic economists worry that a green light to increase regulation will result in excessive meddling in the economy. The regulation may introduce more distortions than it is meant to solve, especially if it is left in place over long periods of time. As markets change, the optimal regulations need to change. Controls that are in place for a long time invite evasion and corruption (if only soft corruption - subconscious favoritism.)

Perhaps a way to avoid or lessen the chance of this problem is through the role of supranational organizations. The FSB, BIS, and IMF can evaluate national-level regulations and offer opinions on their efficiency and effectiveness. Regional bodies also play a role because they might be more sensitive to the differing objectives of countries at different levels of economic and financial development. These regional groups can also coordinate policies to ameliorate spillovers from one country to another country in the region.

Financial globalization is desirable. Mishkin (2006) makes a strong case that emerging market and low-income countries stand to make great gains by integrating into the global financial system. Stronger global macroprudential regulation, coupled with modest counteryclical capital controls on short-term and foreign-currency denominated loans will reduce the risk of opening financial markets. 


\section{References}

Acharya, Viral V. 2003. "Is the International Convergence of Capital Adequacy Regulation Desirable?” Journal of Finance 53, 2745-2781.

Aiyar, Shekhar; Charles W. Calomiris; and, Tomasz Wieladek. 2014a. "Does Macro-Pru Leak? Empirical Evidence from a UK Natural Experiment.” Journal of Money, Credit and Banking 46, 181-214.

Aiyar, Shekhar; Charles W. Calomiris; and, Tomasz Wieladek. 2014b. "Identifying Channels of Credit Substitution when Bank Capital Requirements are Varied.” Economic Policy 29, 45-77.

Aiyar, Shekhar; Charles W. Calomiris; John Hooley; Yevgeniya Korniyenko; and, Tomasz Wieladek. 2014c. “The International Transmission of Bank Capital Requirements.” Journal of Financial Economics 113, 368-382.

Baba, Chikako, and Annamaria Kokenyne. 2011. "Effectiveness of Capital Controls in Selected Emerging Markets in the 2000s.” IMF Working Paper, WP/11/281, International Monetary Fund.

Bank of England. 2011. “Instruments of Macroprudential Policy.” Discussion Paper, December.

Bengui, Julien. 2012. “Macro-Prudential Policy Coordination.” Department of Economics, University of Montreal, working paper.

Benigno, Gianluca; Huigang Chen; Christopher Otrok; Alessandro Rebucci; and, Eric R. Young. 2013. "Financial Crises and Macroprudential Policies.” Journal of International Economics 89, 453-470.

Benigno, Gianluca; Huigang Chen; Christopher Otrok; Alessandro Rebucci; and, Eric R. Young. 2014. "Optimal Capital Controls and Real Exchange Rate Policies: A Pecuniary Externality Perspective.” Centre for Economic Policy Research, discussion paper no. 9936.

Berka, Martin; Michael B. Devereux; and, Charles Engel. 2012. "Real Exchange Rate Adjustment In and Out of the Eurozone.” American Economic Review Papers and Proceedings 102, 179-185.

Berka, Martin; Michael B. Devereux; and, Charles Engel. 2014. "Real Exchange Rates and Sectoral Productivity in the Eurozone.” National Bureau of Economic Research, working paper no. 20510.

Bianchi, Javier. 2011. “Overborrowing and Systemic Externalities in the Business Cycle.” American Economic Review 101, 3400-3426.

Bianchi, Javier. 2013. “Efficient Bailouts.” Working paper, Department of Economics, University of Wisconsin.

Bianchi, Javier, and Enrique Mendoza. 2011. "Overborrowing, Financial Crises, and Macroprudential Policy.” International Monetary Fund, IMF Working Paper no. 11/24.

Bianchi, Javier, and Enrique Mendoza. 2013. “Optimal Time-Consistent Macroprudential Policy.” National Bureau of Economic Research, working paper no. 19704.

Borio, Claudio. 2004. “Towards a Macroprudential Framework for Financial Supervision and Regulation?” BIS Working Papers, No. 128, Bank for International Settlements.

Chinn, Menzie, and Hiro Ito. 2006. "What Matters for Financial Development? Capital Controls, Institutions, and Interactions.” Journal of Development Economics 61, 163-192.

de Gregorio, José. 2011a. "Monetary Policy and Financial Stability: An Emerging Market Perspective.” International Finance 13, 141-156.

de Gregorio, José. 2011b. "Capital Flows and the Interaction between Macroprudential Policy and Monetary Policy.” Keynote speech at the Central Bank of Chile Annual Conference on “Capital Mobility and Monetary Policy,” Santiago, 17 November 2011. 
de Gregorio, José; Sebastian Edwards; and, Rodrigo Valdés. 2000. “Controls on Capital Inflows: Do They Work?” Journal of Development Economics 63, 59-83.

Dell’Ariccia, Giovanni, and Robert Marquez. 2006. "Competition among Regulators and Credit Market Integration.” Journal of Financial Economics 79, 401-430.

Dell’Ariccia, Giovanni; Luc Laeven; and, Robert Marquez. 2011. "Financial Frictions, Foreign Currency Borrowing, and Systemic Risk.” Paper presented at the $12^{\text {th }}$ Jacques Pollak Annual Research Conference, International Monetary Fund, Washington, DC, November 10-11, 2011.

De Long, J. Bradford; Andrei Shleifer; Lawrence H. Summers; and, Robert J. Waldmann. 1990. "Noise Trader Risk in Financial Markets.” Journal of Political Economy 98, 703-738.

Engel, Charles. 2009. “Exchange Rate Policies.” Federal Reserve Bank of Dallas Staff Papers, no. 8, 2009.

Engel, Charles. 2011. "Currency Misalignments and Optimal Monetary Policy: A Reexamination.” American Economic Review 101, 2796-2822.

Evans, Owen; Alfredo M. Leone; Mahinder Gill; and, Paul Hilbers. 2000. “Macroprudential Indicators of Financial System Soundness.” Occasional Paper 192, International Monetary Fund.

Farhi, Emmanuel, and Ivan Werning. 2012. "Dealing with the Trilemma: Optimal Capital Controls with Fixed Exchange Rates.” Department of Economics, Harvard University, working paper.

Fernandez, Andres; Alessandro Rebucci; and, Martin Uribe. 2014. “Are Capital Controls Countercyclical?” Department of Economics, Columbia University, working paper.

Financial Stability Board; International Monetary Fund; and, Bank for International Settlements. 2011a. "Macroprudential Policy Tools and Frameworks: An Update to G20 Finance Ministers and Central Bank Governors.” 14 February, 2011.

Financial Stability Board; International Monetary Fund; and, Bank for International Settlements. 2011b. “Macroprudential Policy Tools and Frameworks: Progress Report to G20.” 27 October, 2011.

Forbes, Kristin; Marcel Fratzscher; Thomas Kostka; and, Roland Straub. 2011. "Bubble Thy Neighbor: Direct and Spillover Effects of Capital Controls.” Paper presented at the $12^{\text {th }}$ Jacques Pollak Annual Research Conference, International Monetary Fund, Washington, DC, November 10-11, 2011.

Forbes, Kristin; Marcel Fratzscher; and, Roland Straub. 2015. "Capital-Flow Management Measures: What Are They Good For?” Journal of International Economics, forthcoming.

Forbes, Kristin, and Francis E. Warnock. 2012. “Capital Flow Waves: Surges, Stops, Flight and Retrenchment.” Journal of International Economics 88. 235-251.

Frankel, Jeffrey A., and George Saravelos. 2012. "Can Leading Indicators Assess Country Vulnerability? Evidence from the 2008-2009 Global Financial Crisis.” Journal of International Economics 87, 216-231.

Galati, Gabriele, and Richhild Moessner. 2013. “Macroprudential Policy - A Literature Review.” BIS Journal of Economic Surveys 27, 846-878.

Ghosh, Atish R.; Jonathan D. Ostry; and, Charalambos G. Tsangarides. 2012. "Shifting Motives: Explaining the Buildup in Official Reserves in Emerging Markets Since the 1980s.” IMF Working Paper, WP/12/34, International Monetary Fund.

Habermeier, Karl; Annamaria Kokenyne; and Chikako Baba. 2011. "The Effectiveness of Capital Controls and Prudential Policies in Managing Large Inflows.” IMF Staff Discussion Note SDN/11/14, International Monetary Fund.

Hanson, Samuel; Anil K. Kashyap; and Jeremy C. Stein. 2011. “A Macroprudential Approach to Financial Regulation.” Journal of Economic Perspectives 25, 3-28. 
Heathcote, Jonathan, and Fabrizio Perri. 2014. “On the Desirability of Capital Controls.” Federal Reserve Bank of Minneapolis, working paper.

Jeanne, Olivier. 2012. “Capital Flow Management.” American Economic Review Papers and Proceedings 102, 203-206.

Jeanne, Olivier. 2013. “Macroprudential Policies in a Global Perspective.” National Bureau of Economic Research, working paper no. 19967.

Jeanne, Olivier, and Anton Korinek. 2010. "Excessive Volatility in Capital Flows: A Pigouvian Taxation Approach.” National Bureau of Economic Research, working paper no. 15927.

Jeanne, Olivier, and Anton Korinek. 2013. "Macroeconomic Regulation Versus Mopping Up After the Crash.” National Bureau of Economic Research, working paper no. 18675.

Jeanne, Olivier; John Williamson; and Arvind Subramanian. 2012. Who Needs to Open the Capital Account? (Washington, DC: The Peterson Institute for International Economics).

Kara, Gazi. 2014. "Systemic Risk, International Regulation, and the Limits of Coordination.” Board of Governors of the Federal Reserve System, working paper.

Klein, Michael. 2012. “Capital Controls: Gates versus Walls.” Brookings Papers on Economic Activity, Fall 2012, 317-367.

Korinek, Anton. 2011a. “Hot Money and Serial Financial Crises.” IMF Economic Review 59, 306339.

Korinek, Anton. 2011b. “The New Economics of Prudential Capital Controls: A Research Agenda.” IMF Economic Review 59, 523-561.

Korinek, Anton. 2014. "Regulating Capital Flows to Emerging Markets: An Externality View.” Department of Economics, Johns Hopkins University, working paper.

Magud, Nicholas E.; Carmen M. Reinhart; and, Kenneth S. Rogoff. 2011. "Capital Controls: Myth and Reality - A Portfolio Balance Approach.” National Bureau of Economic Research, working paper no. 16805.

Mishkin, Frederic S. 2006. The Next Great Globalization: How Disadvantaged Nations Can Harness Their Financial Systems to Get Rich (Princeton).

Obstfeld, Maurice. 2012. “Financial Flows, Financial Crises, and Global Imbalances.” Journal of International Money and Finance 31, 469-480.

Obstfeld, Maurice; Jay C. Shambaugh; and, Alan M. Taylor. 2009. "Financial Instablity, Reserves and Central Bank Swap Lines in the Panic of 2008.” American Economic Review Papers and Proceedings, 480-486.

Obstfeld, Maurice; Jay C. Shambaugh; and, Alan M. Taylor. 2010. "Financial Stability, the Trilemma, and International Reserves.” American Economic Journal 2, 57-94.

Ostry, Jonathan D.; Atish R. Ghosh; Karl Habermeier; Marcos Chamon; Mahvash S. Qureshi; and, Dennis B.S. Reinhardt. 2010. “Capital Inflows: The Role of Controls.” IMF Staff Position Note, SPN/10/04, International Monetary Fund.

Ostry, Jonathan D.; Atish R. Ghosh; Marcos Chamon; and, Mahvash S. Qureshi. 2012. "Tools for Managing Financial-Stability Risks from Capital Inflows.” Journal of International Economics 88, 407-421.

Persaud, Avinash. 2009. “Macro-Prudential Regulation.” Crisis Response Note number 6, World Bank.

Reinhart, Carmen M., and Kenneth S. Rogoff. 2009. This Time is Different: Eight Centuries of Financial Folly. (Princeton).

Shearman and Sterling, LLP. 2011. "The New Basel III Framework: Implications for Banking Organizations.” Financial Institutions Advisory and Financial Regulatory Client Publication, March 30, 2011. 
Schmitt-Grohe, Stephanie, and Martin Uribe. 2012. “Prudential Policy for Peggers.” National Bureau of Economic Research, working paper no. 18031.

Shiller, Robert. 2000. Irrational Exuberance. (Princeton).

Unsal, D. Filiz. 2013. "Capital Flows and Financial Stability: Monetary Policy and Macroprudential Responses.” International Journal of Central Banking 9, 233-285. 